\title{
THE RENAL MECHANISM FOR URATE EXCRETION IN MAN ${ }^{1}$
}

\author{
By ROBERT W. BERLINER, JAMES G. HILTON, T. F. YU, AND \\ THOMAS J. KENNEDY, JR. \\ (From the Research Service, First [Columbia] Division, Goldwater Memorial Hospital, and \\ the Department of Medicine, College of Physicians and Surgeons, \\ Columbia University, New York)
}

(Submitted for publication August 31, 1949; accepted, December 5, 1949)

The renal mechanisms by which urate is excreted have not yet been defined and there still is disagreement on several major points.

Previous studies are in accord on one point, that the normal urate clearance in man is only a small fraction of the glomerular filtration rate, usually of the order of 8-10\%. Differing explanations for the relatively low clearance have been offered. Patently, the difference between the clearance of urate and the clearance of inulin must be due either to non-filterability of a large fraction of the plasma urate, to tubular reabsorption of a major fraction of the filtered urate, or to some combination of these two.

Some observers have reported non-filterability of the plasma urate, presumably due to proteinbinding or polymerization, but the magnitude of the bound fraction, $4-24 \%$ (1), and $23 \%$ (2) has not been nearly sufficient to account for the difference between the clearances of urate and inulin. In a number of other studies (3-5) of the behavior of the uric acid of normal serum on ultrafiltration or dialysis, relatively little or no binding has been detected. In our hands ultrafiltrates of 12 normal and 10 gouty plasmas prepared by the technique of Simms (6) contained concentrations of urate averaging $1 \%$ higher than that of the plasma water (7). Complete diffusibility of the plasma urate is in accord with the findings of Bordley and Richards (8) who found that in frogs and snakes the urate concentration of glomerular filtrate was the same as that of plasma with plasma concentrations varying from 1.6 to $9.4 \mathrm{mg} . \%$ in frogs and from 9.6 to $30 \mathrm{mg} . \%$ in snakes, concentrations covering the range of normal human plasma as well as exceeding it by a considerable margin. This is perhaps the most direct and pertinent evidence of the filterability of urate as far as its renal excretion is concerned.

1 Supported in part by a John A. Hartford Foundation Gift for the Study of Gout.
Despite this evidence of filterability in vitro and, at least in lower vertebrates, in vivo, several investigators have held that this is not the situation in man and that the actual amount filtered at the glomerulus is close to the amount excreted. Berglund and Frisk (9) advanced this theory to explain the fairly constant clearance of urate over a moderate range of plasma urate concentrations and a fairly constant ratio of urate to creatinine clearance in a series of patients with a wide range of renal functional impairment. The same hypothesis has been more recently supported by Wolfson and his associates $(2,10,11)$, for reasons similar to those of Berglund and Frisk. In addition, it was suggested that the very low cerebro-spinal fluid urate concentration was due to non-filterability in vivo. The latter position, however, is not tenable since the composition of spinal fluid departs in several respects from that of a plasma ultrafiltrate, the concentration of a number of filterable substances in the spinal fluid being appreciably lower than that in plasma water $(12,13)$. These authors hypothesize that non-filterability of urate is due to polymerization and that urate is excreted by filtration only or by filtration with a small amount diffusing back passively.

The most extensive work on the mechanism of uric acid excretion is probably that of Talbott (14) who reported a number of simultaneous determinations of inulin and urate clearances and the effect of various agents on the clearance ratio. The ratio of urate to inulin clearance was increased by a number of substances (glucose, salicylate, phenol red, diodrast) most of which are known to be actively transported by the tubular cells. Talbott implies that there is an active mechanism for reabsorbing urate but does not comment on its capacity nor on the possible role of such a tubular reabsorptive capacity in regulating either urate excretion or the plasma urate concentration. 
The present studies were undertaken to attempt to answer the latter questions. The number of experiments to be reported is limited, but they are sufficient to show that there is an active mechanism for the reabsorption of urate, to indicate that this mechanism has a definitely limited and measurable capacity, and to permit an evaluation of the role of the tubules in determining urate excretion and regulating the plasma urate concentration.

\section{MATERIAL AND METHODS}

Studies were made on male patients with no known abnormality of urate metabolism or renal function. The diagnosis in most of the subjects was neurosyphilis. All observations were made in the post-absorptive state. Urines were obtained through an indwelling catheter and the bladder washed with saline at the end of each clearance period. Arterial blood samples were secured at the midpoint of each period using heparin as an anticoagulant. Inulin was administered by continuous intravenous infusion. The uric acid administered was dissolved in $0.7 \% \mathrm{Li}_{2} \mathrm{CO}_{3}$ to make a solution of about $0.5 \%$ urate. In some experiments the urate was administered by continuous intravenous infusion arranged to produce steadily rising plasma urate concentrations. In other experiments the urate was administered as two injections of this solution to give a total dose of 11 to $44 \mathrm{mg}$./ kilo. The largest dose administered was about $100 \mathrm{mg}$./ kilo. in a period of two hours 40 minutes.

Inulin in Somogyi zinc filtrates of yeasted plasma and in diluted urine was determined by the method of Harrison (16). Urate in Folin-Wu tungstate filtrates of plasma and in urine was determined by a modification of Benedict's method (17). No correction for non-uric acid chromogen was made in any of these experiments since all critical data were obtained at times when the plasma concentration and urinary excretion of urate had been greatly increased by the administration of solutions of pure urate. At such times the non-uric acid chromogen is a negligible fraction of the total. Complete diffusibility of the plasma urate has been assumed in all calculations.

\section{Toxic reactions}

Nausea and vomiting occurred in about half of the patients who received infusions of the lithium carbonateuric acid solution. One severe reaction occurred in the subject $(\mathrm{Fe})$ who received the largest dose of urate (100 mg./kilo.). Marked oliguria lasting 36 hrs. developed. The BUN rose from 12 to $36 \mathrm{mg} . \%$ in the first two days and fell slowly to normal. The plasma urate which had been as high as $26 \mathrm{mg} . \%$ during the study did not return to its original value for two weeks. (In other studies a normal urate level was attained in 24 to 48 hours.) In addition to the evidence of renal dysfunction, the patient showed alarming neurological manifestations with semistupor, cog-wheel rigidity, unilateral Babinski, and incontinence of urine. These cleared slowly over a period of several weeks. The cause of the toxic effects encountered in these studies is not entirely clear since the urate was administered along with fairly large amounts of alkali and considerable amounts of lithium. In retrospect, it seems not unlikely that the oliguria was attributable to the uric acid since the same effect has been produced with similar doses in dogs (18). However, the other manifestations in Case $\mathrm{Fe}$ were probably due to the lithium administered (about $7 \mathrm{gms}$. of the carbonate) (15). It is of interest that no manifestations of acute gout were produced in spite of plasma concentrations up to $26 \mathrm{mg} . \%$

\section{RESULTS}

A study of the rates of urate filtration, excretion, and reabsorption as the plasma urate level is increased shows the pattern associated with active tubular reabsorption by a mechanism of limited capacity $(\mathrm{Tm})$. Illustrative experiments are shown in Tables I to III. As the amount of urate filtered increases the amount reabsorbed increases, until a maximum rate of reabsorption is reached. Further increases in the filtered load are not associated with a significant change in the amount reabsorbed. It did not seem prudent to increase the load very much beyond that required to saturate the mechanism so that constant reabsorption despite large variation in filtered load was not observed. However, there are no changes in the reabsorbed urate beyond the errors of the determinations as the load is increased from 18.2 to

TABLE I

The reabsorption and excretion of urate at varying filtered loads Patient Fr, age 41. S.A. 1.70M²

\begin{tabular}{|c|c|c|c|c|c|}
\hline Time & $\begin{array}{c}\text { Plasma } \\
\text { urate }\end{array}$ & $\begin{array}{c}\text { Inulin } \\
\text { clearance }\end{array}$ & $\begin{array}{l}\text { Urate } \\
\text { filtered }\end{array}$ & $\begin{array}{c}\text { Urate } \\
\text { excreted }\end{array}$ & $\begin{array}{l}\text { Urate } \\
\text { reabsorbed }\end{array}$ \\
\hline $\min$ & mg. \% & $\operatorname{ml} . / \min$ & mg./min. & mg./min. & mg./min. \\
\hline $\begin{array}{r}0 \\
1 \\
20\end{array}$ & \multicolumn{5}{|c|}{$\begin{array}{l}\text { Priming inulin } 1 \mathrm{gm} \text {. } \\
\text { Infusion started, } 0.33 \% \text { inulin in saline at } \\
6 \mathrm{ml} . / \mathrm{min} \text {. } \\
\text { Infusion changed to } 0.13 \% \text { urate in } 0.2 \% \\
\mathrm{Li}_{2} \mathrm{CO}_{3} \text { and } 0.33 \% \text { inulin in saline at } 6 \mathrm{ml} . \\
\text { min. }\end{array}$} \\
\hline $\begin{array}{c}21-44 \\
44-66 \\
66-85 \\
85-105 \\
124-140 \\
140-155 \\
155-170 \\
170-185 \\
185-200\end{array}$ & $\begin{array}{c}4.57 \\
9.40 \\
12.8 \\
13.9 \\
15.7 \\
16.5 \\
17.3 \\
17.9 \\
17.5\end{array}$ & $\begin{array}{l}126 \\
140 \\
131 \\
131 \\
140 \\
141 \\
140 \\
137 \\
139\end{array}$ & $\begin{array}{l}5.76 \\
13.2 \\
16.8 \\
18.2 \\
22.0 \\
23.2 \\
24.2 \\
24.5 \\
24.4\end{array}$ & $\begin{array}{l}0.75 \\
2.52 \\
4.90 \\
5.28 \\
8.20 \\
10.0 \\
10.6 \\
11.2 \\
10.7\end{array}$ & $\begin{array}{r}5.0 \\
10.7 \\
11.9 \\
12.9 \\
13.8 \\
13.2 \\
13.6 \\
13.3 \\
13.7\end{array}$ \\
\hline
\end{tabular}


TABLE II

The reabsorption and excretion of urate at varying filtered loads Patient Fe, age 51. S.A. 1.94M²

\begin{tabular}{|c|c|c|c|c|c|}
\hline Time & $\begin{array}{c}\text { Plasma } \\
\text { urate }\end{array}$ & $\underset{\text { clearance }}{\text { Inulin }}$ & $\begin{array}{l}\text { Urate } \\
\text { filtered }\end{array}$ & $\begin{array}{c}\text { Urate } \\
\text { excreted }\end{array}$ & $\begin{array}{c}\text { Urate } \\
\text { reabsorbed }\end{array}$ \\
\hline $\min$. & mg. \% & $\operatorname{ml.} / \min$. & mg./min. & $\operatorname{mg.} / \min$. & mg./min. \\
\hline $\begin{array}{r}-1 \\
0\end{array}$ & \multicolumn{5}{|c|}{$\begin{array}{l}4.7 \\
\text { Priming inulin } 1.4 \text { gms. } \\
\text { Infusion started, } 0.4 \% \text { inulin in saline at } \\
6 \mathrm{ml} . / \mathrm{min} \text {. } \\
\text { Infusion changed to } 0.6 \% \text { urate in } 0.4 \% \\
\mathrm{Li}_{2} \mathrm{CO}_{3} \text { and } 0.4 \% \text { inulin in saline at } 6 \mathrm{ml} . / \\
\text { min. }\end{array}$} \\
\hline $\begin{array}{l}18-48 \\
48-67 \\
67-87 \\
87-101\end{array}$ & $\begin{array}{l}10.2 \\
14.2 \\
17.5 \\
19.7\end{array}$ & $\begin{array}{l}141 \\
131 \\
141 \\
141\end{array}$ & $\begin{array}{l}14.4 \\
18.5 \\
24.6 \\
27.7\end{array}$ & $\begin{array}{l}0.5 \\
1.6 \\
4.0 \\
5.8\end{array}$ & $\begin{array}{l}13.9 \\
16.9 \\
20.6 \\
21.9\end{array}$ \\
\hline 101 & \multicolumn{5}{|c|}{ Infusion rate increased to $9 \mathrm{ml} . / \mathrm{min}$. } \\
\hline $\begin{array}{l}101-117 \\
117-132 \\
132-148 \\
148-164 \\
164-178\end{array}$ & $\begin{array}{l}21.4 \\
24.8 \\
25.0 \\
24.8 \\
26.2\end{array}$ & $\begin{array}{l}144 \\
143 \\
149 \\
142 \\
139\end{array}$ & $\begin{array}{l}30.7 \\
35.4 \\
35.6 \\
35.2 \\
36.3\end{array}$ & $\begin{array}{r}8.5 \\
12.0 \\
12.5 \\
13.7 \\
15.5\end{array}$ & $\begin{array}{l}22.2 \\
23.4 \\
23.1 \\
21.7 \\
20.8\end{array}$ \\
\hline
\end{tabular}

$24.5 \mathrm{mg} . / \mathrm{min}$. and from 27.7 to $36.3 \mathrm{mg} . / \mathrm{min}$. respectively in the experiments in Tables I and II.

Results such as those shown were obtained in six experiments on four patients. The pertinent data from these studies are summarized in Table IV. For comparison all figures have been adjusted to a standard surface area of $1.73 \mathrm{M}^{2}$. Particularly worthy of note is the reproducibility

TABLE III

The reabsorption and excretion of urate at varying filtered loads Urate administered as two rapid intravenous injections Patient L, age 47 . S.A. $1.44 \mathrm{M}^{2}$

\begin{tabular}{|c|c|c|c|c|c|}
\hline Time & $\begin{array}{c}\text { Plasma } \\
\text { urate }\end{array}$ & $\begin{array}{c}\text { Inulin } \\
\text { clearance }\end{array}$ & $\begin{array}{l}\text { Urate } \\
\text { filtered }\end{array}$ & $\begin{array}{c}\text { Urate } \\
\text { excreted }\end{array}$ & $\begin{array}{c}\text { Urate } \\
\text { reabsorbed }\end{array}$ \\
\hline $\begin{array}{c}\min . \\
0-20 \\
20-39\end{array}$ & $\begin{array}{c}m g . \% \\
3.0 \\
3.1\end{array}$ & $\begin{array}{c}\text { ml. } / \text { min. } \\
123 \\
126\end{array}$ & $\begin{array}{c}\text { mg. } / \min . \\
3.69 \\
3.91\end{array}$ & $\begin{array}{c}\text { mg. } / \text { min. } \\
0.49 \\
0.42\end{array}$ & $\begin{array}{c}\text { mg. } / \min . \\
3.20 \\
3.49\end{array}$ \\
\hline 40 & \multicolumn{5}{|c|}{ Urate, $22 \mathrm{mg} . /$ kilo. I.V. } \\
\hline $\begin{array}{l}54-68 \\
68-88\end{array}$ & $\begin{array}{l}13.5 \\
10.9\end{array}$ & $\begin{array}{l}120 \\
121\end{array}$ & $\begin{array}{l}16.2 \\
13.2\end{array}$ & $\begin{array}{l}6.1 \\
4.0\end{array}$ & $\begin{array}{r}10.1 \\
9.2\end{array}$ \\
\hline 90 & \multicolumn{5}{|c|}{ Urate, $22 \mathrm{mg} . /$ kilo. I.V. } \\
\hline $\begin{array}{l}100-115 \\
115-135\end{array}$ & $\begin{array}{l}19.0 \\
16.2\end{array}$ & $\begin{array}{l}113 \\
119\end{array}$ & $\begin{array}{l}21.5 \\
19.3\end{array}$ & $\begin{array}{l}9.7 \\
7.3\end{array}$ & $\begin{array}{l}11.8 \\
12.0\end{array}$ \\
\hline
\end{tabular}

TABLE IV

Summary of urate Tm measurements

All values adjusted to surface area $1.73 \mathrm{M}^{2}$

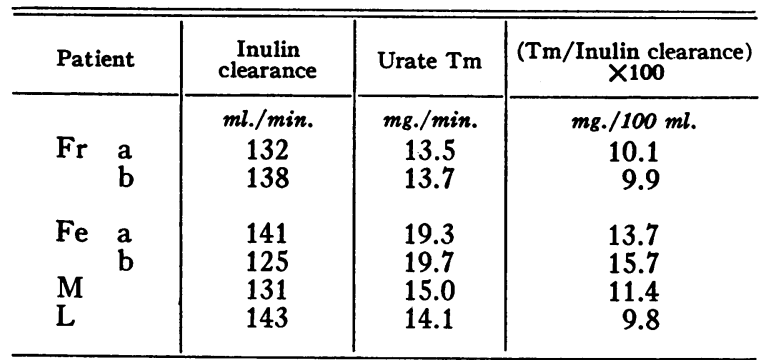

of the $\mathrm{Tm}$ value in the same patient from one time to another. The duplicate experiments on patients $\mathrm{Fr}$ and $\mathrm{Fe}$ were done at two-week intervals. In each instance the $\mathrm{Tm}$ was reproduced within $2 \%$, somewhat less than the errors of the determination, indicating that the reabsorptive capacity for urate is a more or less stable individual characteristic. The ratio of $\mathrm{Tm}$ to filtration rate, shown in the last column, gives the value of the plasma urate at which saturation of the $\mathrm{Tm}$ would occur were the $T \mathrm{~m}$ saturated as soon as the amount filtered exceeded the reabsorptive capacity. The not inconsiderable variation in this ratio is worthy of note. Actually a filtered load considerably greater than the reabsorptive capacity is generally required to insure saturation, so that the ratio in no way represents a "threshold." This is well shown in a series of six additional experiments in which from 8 to $38 \%$ of the filtered load was excreted without evidence of saturation of the Tm (Table $\mathrm{V})$. In the first four of these experiments failure to saturate the reabsorptive mechanism was presumably due to inadequate urate dosage. In the other two sharp drops in filtration rate, ac-

TABLE V

Summary of experiments in which no $T m$ was reached

\begin{tabular}{|c|c|c|c|c|}
\hline Patient & $\begin{array}{c}\text { Total } \\
\text { dose } \\
\text { urate }\end{array}$ & $\begin{array}{l}\text { Highest } \\
\text { plasma } \\
\text { urate }\end{array}$ & $\begin{array}{l}\text { Largest } \\
\text { amount } \\
\text { reabsorbed }\end{array}$ & $\begin{array}{c}\text { Largest } \\
\text { percentage } \\
\text { of load } \\
\text { excreted }\end{array}$ \\
\hline $\begin{array}{l}\mathbf{B} \\
\mathbf{D} \\
\mathbf{M} \\
\mathbf{K} \\
\mathbf{S}\end{array}$ & $\begin{array}{c}\text { mg./kilo. } \\
11^{*} \\
11^{*} \\
22^{*} \\
37 \dagger \\
45 \dagger \\
48 \dagger\end{array}$ & $\begin{array}{c}m g . \% \\
9.7 \\
7.8 \\
13.3 \\
13.5 \\
19.1 \\
14.0\end{array}$ & $\begin{array}{c}\text { mg./min. } \\
9.0 \\
6.6 \\
10.0 \\
10.4 \\
11.8 \\
8.3\end{array}$ & \begin{tabular}{|c|}
$\%$ \\
8.3 \\
13.0 \\
20.0 \\
28.0 \\
24.2 \\
38.3
\end{tabular} \\
\hline
\end{tabular}

* Urate administered in two rapid intravenous injections. $\dagger$ Urate administered by continuous infusion. 


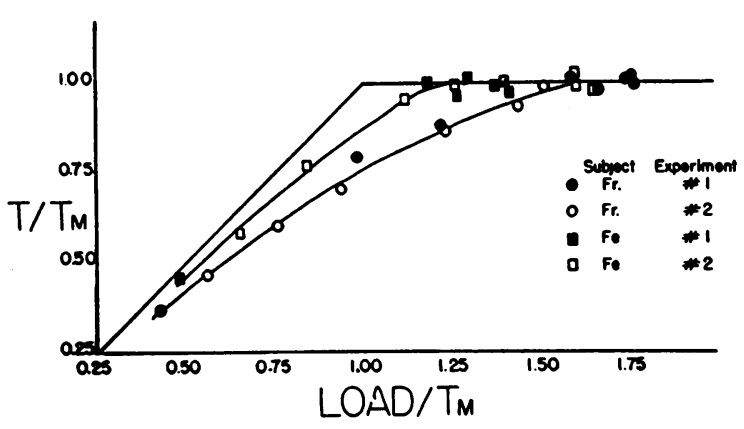

Fig. 1. The Relationship Between Urate Load and URATE REABSORBED

In plotting these data values of $22 \mathrm{mg} . / \mathrm{min}$. and 13.5 $\mathrm{mg} . / \mathrm{min}$. have been used for the Tms of patients $\mathrm{Fe}$ and Fr respectively.

companying nausea and vomiting, were partially responsible for reducing the filtered loads below saturation levels.

The form of the relationship between filtered load and reabsorption is shown in Figure 1. The data from the four experiments on patients $\mathrm{Fr}$ and Fe are plotted in the form used by Smith (19). The amount reabsorbed $(T)$ is plotted against the amount filtered (load). In order to bring all experiments to the same scale both of these quantities have been plotted as fractions of the individual maximum reabsorptive capacities ( $\mathrm{Tm})$. The intersecting straight lines represent the "idealized" situation where the amount filtered is quantitatively reabsorbed until the load is equal to the reabsorptive capacity. Beyond this load the excess is quantitatively excreted. The observed relationships are indicated by the free-hand lines. Noteworthy are 1) the excretion of appreciable amounts of urate at all attainable loads, 2) failure to utilize the full reabsorptive capacity until the load exceeds it by as much as $60 \%$ in patient $\mathrm{Fr}$, and 3 ) the reproducibility of the form of the "titration curve" in successive experiments in the same individual, similar amounts of urate being excreted at similar loads.

\section{DISCUSSION}

These data, although limited in quantity, are sufficient to show that urate excretion is the resultant of glomerular filtration and active tubular reabsorption. Failure to obtain appreciable changes in urate clearance with changes in plasma urate concentration in earlier studies $(9,10)$ is probably attributable to the relatively limited range of plasma concentrations studied.

However, it is clear that the magnitude of the urate reabsorptive capacity is so great that it is almost certainly never saturated in the normal individual. This being the case, the Tm per se cannot be considered as directly involved in the regulation of the plasma urate concentration or even in the regulation of urate excretion. That is, urate excretion is not normally determined by the extent to which the amount filtered exceeds the reabsorptive capacity. The demonstration of a $\mathrm{Tm}$ should be considered only as showing that an active tubular transport mechanism is involved.

The quantitative factors determining the excretion of urate at normal loads remain to be determined. These are the factors which fix the position of the titration curves. The shape of such curves has been discussed by Shannon (20) from the standpoint of the law of mass action as applied to the cellular transporting reaction, and by Smith (19) from the aspect of the distribution of functional capacity among the individual tubules and their conjoined glomeruli. It seems most reasonable that, in considering the titration curve of any transport mechanism, both factors should be taken into account. The assumption (19) that each tubule reabsorbs all of the filtered substance until the load is equal to its maximum reabsorptive capacity can, in the strictest sense, be only approximately true, most nearly so when the equilibrium constant for the reaction between cellular component and transported substance is very small (20). Under such circumstances the "splay" in the titration curve might be largely attributable to disparity between the functional capacity of individual tubules and their attached glomeruli. This appears to be the situation in the case of glucose and of diodrast to which this type of analysis has been applied. However it does not seem reasonable that individual tubular function should be closely correlated to individual glomerular function in the case of glucose but not in the case of other substances such as ascorbic acid $(21,22)$, various amino acids (23), and phosphate (especially in acidosis) (24), where excretion of appreciable amounts well below saturation levels is the rule. The urate mechanism appears to fall in the latter category. Indeed, adequate fits to the observed titration curves can be calculated using the equa- 


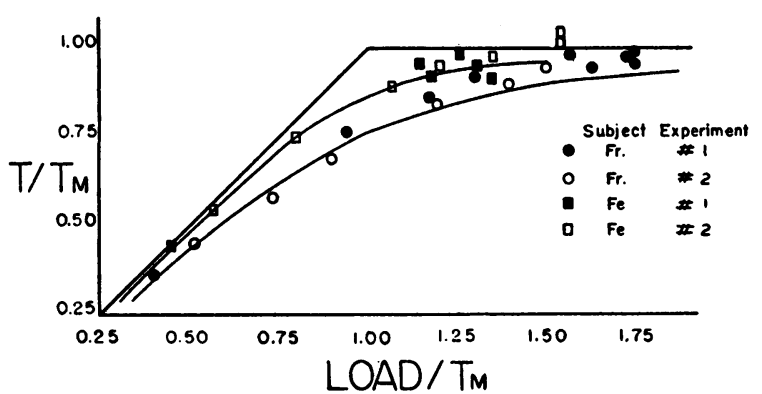

Fig. 2. The Relationship Between Urate Load and URATE REABSORBED

The data shown in Figure 1 have been replotted. The curves were calculated from the equation (21)

$$
k=a-\left(\frac{T r}{V}\right)\left(\frac{T m-T r}{T r}\right),
$$

where $a$ is the arterial plasma concentration, $\operatorname{Tr}$ the amount reabsorbed at any plasma concentration, and $\mathrm{V}$ the volume of glomerular filtrate. For patient $\mathrm{Fe}$ a value of $23 \mathrm{mg} . / \mathrm{min}$. has been used for $\mathrm{Tm}$ and 0.4 for $\mathrm{K}$. The values for patient $\mathrm{Fr}$ were 14 and 0.8 respectively.

tion derived by Shannon from consideration of the law of mass action as applied to the reaction between transported substance and the intracellular transporting enzyme (Figure 2). The normal excretion of urate is thus determined by both the total transport capacity and the affinity of the transporting system for the substance in question.

It is not clear that the plasma concentration of any substance is regulated by continuous saturation of the renal tubules. (The excretion of sulfate is a probable exception [23].) In most cases, in fact, the normal plasma concentration is well below that necessary to bring the filtered load up to the $\mathrm{Tm}$ much less to saturate the reabsorptive capacity, for which purpose appreciably higher loads are generally required. It is reasonable to question to what extent even urinary excretion is determined by the margin by which the filtered load exceeds the reabsorptive $\mathrm{Tm}$. In most instances which have been investigated (phosphate, amino acids, ascorbic acid) the bulk of normal excretion occurs without saturation of reabsorptive capacity. In this respect, the urate mechanism is no exception.

\section{SUMMARY}

1. A study of the clearances of inulin and urate over a wide range of plasma urate concentrations indicates that urate is excreted by glomerular filtration and active tubular reabsorption. The lat- ter process is characterized by a limiting maximum rate of the order of $15 \mathrm{mg} . / \mathrm{min}$. per $1.73 \mathrm{M}^{2}$ in four normal males and in a given individual is reproducible from one time to another within the limits of error of the methods.

2. The magnitude of the $\mathrm{Tm}$ is such that it is almost certainly never saturated under physiological conditions.

3. Factors determining the excretion of substances at concentrations lower than those required to saturate the tubular reabsorptive mechanisms are discussed.

\section{BIBLIOGRAPHY}

1. Adlersberg, D., Grishman, E., and Sobotka, H., Uric acid partition in gout and in hepatic disease. Arch. Int. Med., 1942, 70, 101.

2. Wolfson, W. Q., Levine, R., and Tinsley, M., The transport and excretion of uric acid in man. I. True uric acid in normal cerebrospinal fluid, in plasma, and in ultrafiltrates of plasma. J. Clin. Invest., 1947, 26, 991.

3. Chabanier, H., Lebert, M., and Lobo-Onell, C., De l'état de l'acide urique dans le sérum sanguin. Compt. Rend. Soc. de Biol., 1922, 87, 1269.

4. Delaville, M., and Jones, C., Le dosage de l'acide urique dans le plasma sanguin. Compt. Rend. Soc. de Biol., 1925, 92, 522.

5. Achard, C., Levy, J., and Marinowski, Z., Sur l'acide urique ultrafiltrable. Compt. Rend. Soc. de Biol., 1932, 111, 366.

6. Simms, H. S., and Sanders, M., Use of serum ultrafiltrate in tissue cultures for studying the deposition of fat and for propagation of viruses. Arch. Path., 1942, 33, 619.

7. Yü, T. F., Hilton, J. G., Kennedy, T. J., Jr., and Berliner, R. W., Unpublished data.

8. Bordley, J., 3rd, and Richards, A. N., Quantitative studies of the composition of glomerular urine. VIII. The concentration of uric acid in glomerular urine of snakes and frogs, determined by an ultramicroadaptation of Folin's method. J. Biol. Chem., 1933, 101, 193.

9. Berglund, H., and Frisk, A. R., Uric acid elimination in man. Acta med. Scandinav., 1935, 86, 233.

10. Wolfson, W. Q., and Levine, R., The transport and excretion of uric acid in man. IV. The renal mechanism for urate excretion. Federation Proc., 1948, 7, 136.

11. Wolfson, W. Q., Cohn, C., Levine, R., and Huddleston, B., Transport and excretion of uric acid in man. III. Physiologic significance of the uricosuric effect of caronamide. Am. J. Med., 1948, 4, 774.

12. Shannon, J. A., The relationship between chemical structure and physiological disposition of a series of substances allied to sulfanilamide. Ann. N. Y. Acad. Sci., 1943, 44, 455. 
13. Wallace, G. B., and Brodie, B. B., The passage of bromide, iodide and thiocyanate into and out of the cerebrospinal fluid. J. Pharmacol. \& Exper. Therap., 1940, 68, 50.

14. Talbott, J. H., Gout. Oxford University Press, 1943.

15. Corcoran, A. C., Taylor, R. D., and Page, I. H., Lithium poisoning from the use of salt substitutes. J. A. M. A., 1949, 139, 685.

16. Harrison, H. E., A modification of the diphenylamine method for the determination of inulin. Proc. Soc. Exper. Biol. \& Med., 1942, 49, 111.

17. Benedict, S. R., and Franke, E., A method for the direct determination of uric acid in urine. J. Biol. Chem., 1922, 52, 387.

18. Folin, O., Berglund, H., and Derick, C., The uric acid problem; experimental study on animals and man including gouty subjects. J. Biol. Chem., 1924, 60, 361.

19. Smith, H. W., Lectures on the Kidney. University Extension Division, University of Kansas, 1943.
20. Shannon, J. A., Renal tubular excretion. Physiol. Rev., 1939, 19, 63.

21. Ralli, E. P., Friedman, G. J., and Rubin, S. H., The mechanism of the excretion of vitamin $\mathrm{C}$ by the human kidney. J. Clin. Invest., 1938, 17, 765.

22. Friedman, G. J., Sherry, S., and Ralli, E. P., The mechanism of the excretion of vitamin $C$ by the human kidney at low and normal plasma levels of ascorbic acid. J. Clin. Invest., 1940, 19, 685.

23. Pitts, R. F., A comparison of the renal reabsorptive processes for several amino acids. Am. J. Physiol., 1943-44, 140, 535.

24. Schiess, W. A., Ayer, J. L., Lotspeich, W. D., and Pitts, R. F., The renal regulation of acid-base balance in man. II. Factors affecting the excretion of titratable acid by the normal human subject. J. Clin. Invest., 1948, 27, 57.

25. Lotspeich, W. D., Renal tubular reabsorption of inorganic sulfate in the normal dog. Am. J. Physiol., 1947, 151, 311. 